\title{
The Functional Transformation of the Political World: Reflections on Habermas
}

by Darrow Schecter

First published in Studies in Social and Political Thought 1, 1999.

There are several possible ways of trying to understand Jürgen Habermas's social and political thought. The first is perhaps best described in terms of Habermas's position as the intellectual conscience of the left wing of the German SPD. Habermas's thinking can be in part explained as an intellectual defence of the more critically thinking wing of German Social Democracy, especially during the Cold War, that is, until 1989. Thus Habermas's ideas on the 1968 student revolts and the really interesting works of his middle period, such as Legitimation Crisis, can be seen as an attempt to stake out a critical, independent, left-wing position for the SPD in response to the student revolts and the emerging corporatist order in Germany in the early 1970s. In conjunction with this civic position, Habermas was called upon to assume the role of spokesperson for the institutional German left on questions like the Cold War, the non-democratic implications of corporatism, the terrorism of the 'deutscher Herbst' of 1977, and then the critique of German social and political institutions under the Christian Democratic leadership of Helmut Kohl, the CDU chancellor recently upstaged in the parliamentary elections of last September. Habermas provided a kind of intellectual integrity to the decision of the German Social Democratic Party to attempt to maintain a fairly left perspective on worker participation in industry and related issues, but nonetheless to abandon the idea of revolution in order to make 'the long march through the institutions.'

A second perspective On Habermas might locate him in the trajectory of social and political theory that runs roughly from Marxism to critical theory, and from there to discourse theory. This trajectory might be considered a 'Verfallsgeschichte,' a history of decay or decline, charting Habermas's uneasy, at times Aristotelian appropriation of Marxism, and 
Marxism's subsequent consignment to a very uncertain status within discourse ethics, as part of the project of championing a theory and politics of communicative action. Perhaps the most interesting facet of this defence of discourse theory in Habermas's work is the residual critical theory, i.e. Frankfurt School, moment in his thinking. In different ways, Knowledge and Human Interests, The Theory of Communicative Action and other writings suggest that there is a moment of truth in liberalism that simultaneously points beyond liberalism. Habermas often appears to retain the Frankfurt School conviction that if liberalism in institutional practice would remain committed to the link between freedom and autonomy as it did during the Enlightenment, rather than merely the link between freedom and interest as it did thereafter, then liberalism would in practice start to look much more like Marxism than liberalism.

This anticipates a third possible way of looking at Habermas's thought, which will provide the focus for the argument here. It will be argued that there is a specifically modern and German dimension to Habermas's thinking which is linked to but also separate from his role as the intellectual voice of the left wing of the SPD during and after the Cold War, and different too from his place in the movement from Marxism to critical theory and from there to discourse theory. By acknowledging these first two aspects of his thinking but choosing to focus on a third approach, one can investigate Habermas's place in a specific intellectual tradition concerned with attempting to defend the integrity of 'the political' against the encroachments of economic, administrative, social, aesthetic, functionalist and ontological discourses and practices. Striking in this context is that after Kant, there is virtually no attempt to ground the legitimacy of the state or the specificity of politics in terms of contract or droit civil in any major German political thinker. While this is most obviously true of Hegel, it is also true of thinkers whom one might broadly characterise as politically liberal, such as Max Weber. In what follows, I will briefly chart the main currents in that tradition of defending the integrity of the political, before moving on to Habermas's role in these debates to see where he takes them. It will be argued that Habermas fails to defend the integrity of politics, but that this is not as interesting as the specific reasons why he is not able to defend politics against the colonisation of the political by economic, social and functionalist arguments and practical interests. I will now very briefly outline the contours of the defence of the political in modern Germany in which Habermas's ideas are situated by quickly looking at the ideas of four highly representative thinkers of that tradition before examining Habermas's views. They are: Kant, Hegel, Carl Schmitt and Hannah Arendt. 


\section{II}

Kant's role in this tradition is a little ambiguous, since his defence of natural law and his insistence on the primacy of morality and ethics over politics would seem to situate his ideas in a liberal framework in ways which clearly set him apart from Hegel, Schmitt and Arendt. Nonetheless, the political dimension of his project consists in a rigorous attempt to specify the best amongst the possible forms of mediation between the private domain of ethics, natural law, morality and individual conscience, on the one hand, and the institutions of political authority and positive law, on the other. He argues that in modern societies there is a public sphere mediating between the private views of independent private citizens and the state. For anyone already somewhat familiar with the broad outlines of Habermas's social and political thought, it is obvious that there is a deep affinity between the spirit of Kant's What Is Enlightenment?, On the Common Saying... and The Dispute of the Faculties, with Habermas's project in The Structural Transformation of the Public Sphere (1962) and the more recent Between Facts and Norms (Faktizität und Geltung, 1992). Kant argues that an assembly of independent citizens, as a collective body of non-governing, and economically-independent 'burghers,' will, through open discussion, arrive at value positions which transcend the sphere of their economic interests, on the one hand, and exert a politically-informed universal ethical pressure on state authority, on the other. Kant's theory of the public sphere is not so much a defence of the integrity of the state of the kind found in Hegel, as an analysis of the political dimension of the legitimation of power in paradigm liberal instances such as freedom of assembly, un-coerced speech, and bourgeois public life generally. Implicit in Kant's scattered political writings (there really is no political 'critique' in the sense of those of pure reason, practical reason and judgement) is the idea that there are more reactionary and less reactionary reasons to limit political participation to economically independent citizens. Less reactionary from Kant's standpoint is the idea that without a measure of economic independence, individuals will almost certainly be able to do little other than defend their material interests in the public sphere. In this case the public sphere forfeits its ethical dimension as a force for progressively harmonising natural and positive law. This would be to go against the grain of enlightenment and progress in history, which in political terms for Kant is a process mediating the claims of freedom and authority in increasingly perfect forms. He is confident that given the proper balance of natural law-based property rights, the public sphere, and political authority, the distinction between liberty and law will someday lose importance in an international community of cosmopolitan citizens. His 
position is neither classical, republican, or straightforwardly liberal; Kant's emphasis on the ethical and communicative dimension of the public sphere raises the possibility of non-instrumental political action with universal claims well beyond the partial claims of different interest positions, without which political authority is merely legally codified power rather than genuine authority. Kant argues that by way of the public sphere, political authority is legitimated on a far more universal basis than that which merely parliamentary majorities or executive decisions by themselves can provide. Thus he thinks to have successfully demonstrated that Hobbes is wrong to claim that authority rather than truth is the source of legislative mandate, since the political and ethical pressure of public sphere discussion ensures that modern forms of law increasingly become a register of discursive truth rather than merely a barometer of force or interest.

In the Philosophy of Right of 1821 Hegel demotes the idea of the public sphere to the much more pejorative notion of public opinion. The parallel movement in Hegel, however, is to elevate the state to the most elevated and fully conscious expression of objective spirit within the totality of ethical life. For Kant ethics and morality are matters of individual conscience; the state regulates external behaviour, while the public sphere mediates between private, ethically motivated individuals and the state. This understanding of the relationship between individual liberty and political authority is deeply unsatisfying to Hegel, who thinks that Kant's priority of natural law and liberalism places the individual and the state at war. Hegel suggests that Kant's political philosophy corresponds to a period in which the material reproduction of society could still be considered a private activity which might be confined within well-defined boundaries largely defined by land ownership and transparent forms of exchange. Kant's reasoning suggested that although it was true that the economy had broken the boundaries of the family, economic growth and development were still largely matters of property. However, his reading of Smith, Steuart, Ferguson, and J.B. Say convinced Hegel that the Kantian period was now over, since the economy had assumed a breadth hitherto unknown in Europe which burst previous restrictions on economic forces asunder. Key in this context is Hegel's correct intuition that the expansion of economic forces had completely changed the dimensions of civil law and civil society, and, in so doing, challenged the integrity of the state in unprecedented ways. Thus while one is sometimes wont to read Hegel as the metaphysician of the state and of reconciliation/recognition, and the theorist of 'objektiver Geist,' one would probably also be warranted in reading the Philosophy of Right as a theoretical defence of the Prussian administrative reforms of this period, designed to allow the emerging German industrial bourgeoisie a certain degree of 
economic liberty, while at the same time ensuring that ultimate authority transcended economic interests in civil society.

While at least at the level of theory, it was previously possible to subsume the economy under the category of the private, and to identify the civil sphere with the state, Hegel's political philosophy registers the expansion of the economy in a period where it for the first time comes to include and indeed dominate civil society. Thus for Hegel civil society, which was once synonymous with the state and did not include the economy, comes to include the economy, i.e. what Hegel calls the system of needs, while the state emerges as a separate political idea. Hegel insists in this context that only the state can act as the reality of the ethical idea, and moreover that the good of individuals and the good of the state are separate things. In Hegel's defence of the political, the state has its own concrete existence, which does not depend on Kantian maxims informing individual moral behaviour. Key for the discussion of Habermas to follow is Hegel's insistence that the security of property and personal freedom are matters related to what he refers to as abstract right and the administration of justice, but that they cannot be the basis of the state which is, for Hegel, the highest moment in the unfolding of objective spirit. Hegel's critique of Kant proceeds along the following lines: although the notion of the public sphere seems to invoke non-contractual and non-utilitarian forms of collective discussion and action, Kant's public sphere is nonetheless subordinated to the private interests of the independent property owners who constitute it, and this leaves the state with a highly inadequate foundation (Hegel prefers to assign non-utilitarian forms of pre-state action to the corporations of civil society rather than the Kantian public sphere). Hegel argues that since valid contract presupposes the state, there must be a pre-economic and pre-contractual foundation of ethical life that enables particular contracts to achieve validity. This prior, non-contractual instance of politics is absent in Hobbes, Locke, and Rousseau, and clearly places Hegel in the modern German tradition of political thought sketched here. In Hegel's writings the state is more than just another contract. It represents the pre-contractual unity of different minds making contract itself merely one of several constitutive moments of ethical life as a whole in a single, richly mediated intersubjective (not otherworldly) mind that Hegel calls Geist. Thus the state is not a modified form of contract at all - it enacts forms of recognition and agreement that encompass and go beyond the utilitarian forms of interest and calculation negotiated in contractual relations. It is precisely this ontological defence of the integrity of the state that Feuerbach and Marx reject, and which prompts them to seek the real source of politics in productive and other forms of collective interest in civil society. In this light, it becomes clear that 
Habermas's thought is not so deeply influenced by Marx as it is by Kant and to a lesser extent Aristotle and Hegel. The nodal point of this link with Kant and Hegel is Habermas's search to define a sphere and a related set of principles beyond class and other forms of interest, i.e. to find a more modern and sociologically less naive synthesis of Kant on the public sphere and Hegel on the state. It is certainly important to remember that any comparison with Kant and Hegel must be qualified by the fact that Habermas does not write in terms of the transcending of interest as such, but rather proceeds in terms of a distinction between different forms of interest and their semi-functionalist reconciliation as different inputs to lifeworld interaction and systemic steering mechanisms. Nonetheless, this is where Habermas begins to run into difficulty, since in order to distinguish his position both from a naive version of Kantian ethics and from Niklas Luhmann's thoroughgoing functionalism, Habermas reserves a privileged status for politics and law as instances where particular individuals with divergent interests can recognise themselves as collective legislators in a community of citizens. Within this framework, the legitimacy of the state resides beyond the efficiency of the economy and the satisfaction of material forms of need, which are essentially related to technical interests, and is rooted instead in practical and emancipatory interests that presuppose the satisfaction of material necessity but also open up the possibility of more consensual forms of interaction and understanding than are ever possible in contractual or economic relations.

This puts Habermas in an at first glance strange proximity with Carl Schmitt, who like Hegel is determined to demonstrate the integrity of the political beyond class and other particular interests. Schmitt argues for the integrity of politics neither in the terms of the public sphere or even the state, but rather in terms of what he calls 'the political' which, in the opening line of The Concept of the Political (1932), he says precedes and presupposes the state. The expository literature on Schmitt in recent years has paid a great deal of attention to the idea of the friend-enemy distinction developed in The Concept of the Political and to Schmitt's statement in Political Theology (1922) that all significant attempts to derive a theory of sovereignty for the modern state such as Rousseau's or Hegel's are in the last instance theological in nature. However, the Habermas-Schmitt link is not to be found in either The Concept of the Political or Political Theology, but rather in less well-known works such as The Crisis of Parliamentary Democracy (1923) and Legality and Legitimacy (1932). In these writings Schmitt is very close to positions defended by both Marx as well as the Marxist legal theorist of the Weimar period Otto Kirchheimer. Schmitt's argument, which uncannily foreshadows certain elements of Habermas's Structural Transformation of the Public Sphere and the later Legitimation Crisis, is that under the economic and social 
conditions prevailing in modern industrial capitalism, the legislature is constantly deprived of its normative foundation as an institution for the expression of political values. Instead the state becomes an executive committee, not for the managing of the affairs of the entire bourgeoisie, as Marx and Engels would have it in 1848, but for producing class compromises between the various factions of capital and the at that time recently enfranchised working classes. In other words, the legislature becomes a committee for the adjudication of private material claims rather than a forum for the expression of consensual or communicative values and positions which might confer political equality (citizenship in the broadest sense): that universal quality which in liberal theory separates political freedom from the more openly conflictual codes governing property, exchange, contract and civil law generally. There is a great deal at stake here, since if it can be demonstrated that civil freedoms and the inequalities attendant to them are reinforced rather than neutralised by political freedoms, Schmitt will have unwittingly helped Marx make his argument in On the Jewish Question (1843) seem even more convincing than it was at the time Marx was writing against Hegel.

Schmitt initially hoped that all elements in German society might meet in parliament to discuss the value orientations of the newly founded Weimar Republic. Like Weber, he thought that parliamentary institutions might be able to serve as a kind of school for the formation of a political élite. Schmitt did not regard this possibility in Pareto's or Mosca's more pejorative sense of élites, but rather as a source of values and political legitimacy against the increasing encroachments of the economy, bureaucracy and the gradual transformation of rationality into rationalisation. However, as Weber and in some ways even more dramatically Schmitt were to show, this possibility for the non-instrumental evolution of parliamentary democracy is effectively precluded by the sabotaging and undermining of parliamentary institutions by the material-economic demands of capital and labour. Within the framework established by the private ownership and control of the means of production in practice, this clash of interests eventually engenders more (Italy in the 1920s and Germany in the 1930s) or less (Germany and Britain in the 1970s) authoritarian forms of corporatism rather than anything remotely resembling the claims of liberalism in theory. In this process the legislature is in effect deprived of its normative functions and has to content itself, in the context of Weimar and beyond, with exerting a modicum of control on the executive. Yet rather than actually formulating any convincing defence of the political in response, Schmitt's assessment of the Weimar situation and the subsequent dismantling of parliamentary institutions by the National Socialists led him to embrace the Weberian solution of resorting to charismatic leadership as a way of infusing the executive with 'völkisch' 
normative inputs. The defence of the political remains in the last instance almost Derridean - in Schmitt's writings the political is present only in the trace of its absence. This indicates that if Schmitt had had the materialist courage of his political convictions, he would have followed Kirchheimer and consistently argued for the socialist economy needed to make possible the kind of politics Schmitt favours.

The defence of the political and of the integrity of politics against economic, administrative and social intrusions is taken up more successfully in the post-World War II period by Hannah Arendt. Throughout her work, but perhaps especially in The Origins of Totalitarianism (1951) and The Human Condition (1958), is the idea that the essential preparatory steps toward totalitarianism are taken when there is no public or political sphere to challenge the colonising tendencies of the material necessities of production and administration. As in Schmitt, there is a fundamentally anti-capitalist moment in Arendt's political thought which follows Weber in discerning the tendency of modern commodity production to elude systematic confinement within a particular sphere called 'the economy,' and instead to spread its logic and imperatives to both the state and the private sphere. Confirming Hegel's implicit fears in the Philosophy of Right, Arendt argues that modern forms of capitalist economic organisation bring in their wake potentially totalising forms of social organisation, which tend to narrow or even eliminate a specifically political moment of communication and opposition. While one might characterise the political moment in Schmitt's thinking as a theological-political form of Catholicism informed by a sociological analysis of conflict, Arendt's arguments for the primacy of the political have a more classical lineage, which locates the integrity of the political outside of the sphere of material production and necessity, i.e. on the classical analogy, in the polis, into which family and economic matters should not intrude. For Arendt, modern forms of totalitarianism eliminate the space of politics, in such a way that the technical imperatives of the economy impose a logic of instrumentality on all other spheres. The reification of human relations and by extension of humans themselves leads to their classification as things rather than people, which for Arendt was an indispensable precondition for the project to selectively exterminate them undertaken by the National Socialist regime in the 1940s.

On the one hand, Arendt's dispute with capitalism and the bourgeoisie is that the bourgeois class opened the door to totalitarianism, not because of its politically right-wing prejudices, but more precisely because of its anti-political indifference to the necessity of a public sphere to check both the colonising logic of capitalist economic processes and the swelling administrative and regulatory adjuncts of bureaucratic state power. 
Because of its commitment to commerce and trade, the bourgeoisie is in its very essence indifferent to politics, and is concerned only that the orderly conduct of business be able to proceed with minimal interference. Hence the bourgeois class was fundamentally in open accord with the fascist dictatorships in Europe because of their promise to restore order, and instead, especially in Germany, they received the entire National Socialist programme. On the other hand, Arendt's dispute with Marx might run as follows: no matter how one organises the economy, it will always be governed by technical, means-ends, i.e. instrumental criteria, such that it can never be a sphere of liberty, but will always be a sphere whose scope is always quite narrowly defined by technical and utilitarian criteria. Thus for Arendt it is not the case that the working class is incapable of selfgovernment. It is, rather, that there is little scope for political virtues such as courage and honesty when one is 'making things,' i.e. producing: courage, insight and honesty are actually impediments in activities which call for precision, speed and efficiency. While fascist totalitarianism resulted in part as a consequence of the bourgeoisie's fundamentally anti-political tendencies, Stalinism in Russia and its satellite states was organised as a social dictatorship, that is as a dictatorship which also, albeit in a very different way, eliminated the space of the political in the name of the technical exigencies of industrial modernisation in narrowly utilitarian terms.

\section{III}

Arendt's insistence on the irreducibility of the political to the technical or social or economic, and her corollary insistence that liberty can only be exercised in a space for politics, is taken up, albeit in quite drastically modified form, by Habermas. Like Kant, Hegel, Schmitt and Arendt, Habermas attempts to argue that democratic politics and political liberty are only possible where democracy is more than simply a compromise between social classes, and politics is more than simply the technical means necessary to secure that compromise. In part Habermas might be seen as attempting to re-interpret Arendt's diagnosis of the interwar period and her demonstration that the process of securing class compromise can take an extremely authoritarian turn under both advanced capitalism and state socialism. Contrary to Arendt's attempt to combine the critique of instrumental rationality and capitalism which she reads out of Weber and Heidegger with a defence of classical, renaissance and (1956) Budapest republicanism, Habermas attempts to argue for the irreducibility of democracy and the state to property relations and class compromise through 
the practice of domination-free communication in the lifeworld and the institution of law at the level of state. For reasons of space, the following remarks on Habermas's project will have to leave aside both the analysis of Öffentlichkeit in The Structural Transformation of the public Sphere (1962) and the theory of universal pragmatics and communicative praxis in the Theory of Communicative Action (1981), which is heavily inspired by Schutz, Arendt, and Apel. Instead, the argument here is largely based on Habermas's defence of the law and civil society in the more recent Between Facts and Norms (1992). This latter work can be seen as a post-1989 elaboration and updating of themes in the earlier writings. But whereas the previous texts defend the public sphere and communicative praxis as non-instrumental forms of action which legitimate political authority, Habermas's post-Cold War writings emphasise the political dimension of law. This shift in emphasis and the recent focus on law and civil society in his work in the current decade mark an attempt to develop a theory of political legitimation which acknowledges the systemic complexity of economic and administrative processes, but which also insists on egalitarian forms of citizen participation as the ultimate basis of a legitimate polity. Thus Habermas thinks it is possible within the boundaries established by global capitalism to institute non-plebiscitary forms of politics in civil society which can hold bureaucracies and centres of executive power accountable to the citizen-legislators of contemporary civil societies.

In Between Facts and Norms Habermas submits that in law, as distinct from the state with its police, military and bureaucratic apparatus, we can see the various forms of recognition in civil society mapped out as a kind of topography of the socio-political; law provides us with a hermeneutic key for interpreting different social and political conflicts and their mediation. As in Hegel's defence of the state, Habermas refuses to universalise or generalise the contractual moment of social and political action, and like Hegel he sees contract and the possibility of the validity of contract as embedded in a wider system of communicative action. While for Hegel this wider context is 'Sittlichkeit,' or ethical life, in Habermas it takes shape in the distinction and separation between system and lifeworld, or, as in Between Facts and Norms, between (a) civil society as a network of autonomous public spheres, (b) the political and administrative system, and (c) the sphere of economic processes of material reproduction (Faktizität und Geltung, p. 363). Contrary to both communitarian notions about the insufficiency of civil law and strictly negative conceptions of freedom, as well as Marxist notions about the superfluousness of politics in a postcapitalist society, Habermas remains committed to a participatory and communicative answer to the question of how to mediate conflict in other 
than merely technical or redistributive terms. He asserts that universal forms of conflict adjudication reveal themselves on the horizon of legal rationality, and that the promise of fully consensual forms of agreement may well be fully redeemed once the citizens of the modern state are able to recognise themselves as the authors of those laws that govern their life together in a political community. This ability of citizens to recognise themselves as the authors of the laws is only possible in its turn on the basis of what Habermas calls a radical democracy anchored specifically in the communicative network of the public sphere in particular, and in civil society generally (Faktizität und Geltung, pp. 51-2). Habermas borrows from the young Hegel's critique of Kant, to argue for the move from practical reason to communicative reason and praxis. In contrast to the potentially atomistic and narrowly legalistic interpretations of the former, communicative action holds out the promise of the broadest possible, i.e. anthropological, significance of law as the basis of an instance of what Habermas calls 'thisworldly transcendence' (Faktizität und Geltung, p. 19).

According to this line of reasoning, the moment of legally codified consensus is post-metaphysical, even though in Habermas's terms it is also transcendent. In Habermas's formulation, liberal political freedoms such as those of expression, assembly, and political participation can really work toward making political authority legitimate as the work of the collective, assembled citizenry. For Habermas this is precisely what occurs when communication is anchored in civil society as the basis of a network of autonomous public spheres. However, Habermas is also adamant that the very political system which excludes domination-free communication, and which by his own admission is run by quasi-corporatist economic interests and administrative power of the kind diagnosed by Schmitt and Weber, must rule. Moreover, the capitalist economy is no longer a solvable problem for Habermas, since money and power have insulated themselves in systemic isolation against any democratic impulses of a non-economic, i.e. political, nature in civil society. Habermas thus forfeits any points of agreement he might have had with Arendt on communicative action and Schmitt on the critique of corporatism. The result is that within his framework, communicative action never becomes communicative power. The attempt to separate the technical, practical, and emancipatory dimensions of interest, and simultaneously to argue that there is a functional harmony between all three in complex industrial societies, suggests that even the best attempts to theorise consensual politics within a capitalist economy will result in preMarxist normative positions. Habermas ends up sounding at times like Aristotle and Feuerbach and at other times like Kant and Hegel, seemingly in the hope that appeals to the universal dimensions of speech, law and 
systems will prevent anyone from noticing. Habermas's concessions to Weber's theory of rationalisation and Niklas Luhmann's theory of autonomous systems induce Habermas to repeat what has by now become the stock-in-trade of Held, Bobbio and other 'left' liberals: post-traditional societies have become far too complex and systemically differentiated for any ideal of democratic self-government to exist in practice. As such, the democratic and political impulses in civil society must remain in systemic isolation from systemic behaviour related to money and administrative power. Although Habermas criticises Luhmann and systems theory in Between Facts and Norms, his own separation of economy/ civil society/ political system (the updated version of the lifeworld/system distinction of the Legitimation Crisis and communicative action period) is highly functionalist - especially in so far as the sub-systems of money and administrative power co-exist in pristine harmony with the political and democratic movements in civil society.

\section{IV}

The attempt to defend the integrity of the political moment of legal equality against class and other forms of interest via law thus fails in Habermas's awkward partial assimilation of Luhmann. Although there is a shift in emphasis from the public sphere to communicative action and from there to law and civil society, Habermas's entire theoretical oeuvre is guided by the correct diagnosis that modern forms of parliamentary democracy tend to lapse into more or less authoritarian forms of corporatism in the search for a stable institutional compromise between clashing interests. Like Schmitt, however, Habermas fails to explicitly draw the appropriate political conclusions from his analysis of political economy. This tendency in Habermas is at times obscured by his erratic eclecticism: Weber and Luhmann are endorsed when it is deemed necessary to give the nod to complexity and systemic differentiation, traces of Schmitt and Weber remain in the critique of corporatism, while gestures are made to the irreducibility of speech and action to contractual forms of negotiation by indirect borrowing from Piaget, Apel and Arendt. The final result is neither Marxism, functionalism, civil society theory, nor a theory of political action. Rather it is a combination of liberal anthropology (with vague theological overtones - Habermas's free speech seems very close to a parish reunion) and legal fetishism.

Habermas defends law as a moment of political universality beyond power, interest and merely formal equality, but because he cannot do this without coming to positions already articulated by Hegel, Marx, Schmitt, or 
Arendt, he is forced to borrow from Luhmann and mainly liberal legal theory. In the end he winds up with a position on politics less coherent and in some respects less radical than Kant's defence of the public sphere. At first sight, the demand for a transition from practical to communicative reason seems to provide politics with a creative, intersubjective dimension anchored in the potentially universal aspects of speech acts. In theory, this dimension would incorporate yet also move beyond liberal versions of neutrality and respect, though without lapsing into communitarian dogmas. But this would be clearly impossible in practice, since the state, or in Habermas's terms the political system, transforms any given struggle for recognition in civil society into a struggle for power or money by channelling all conflicts, whether material or value-oriented, into a steering or integration mechanism such as a political party or government ministry. As long as parties and bureaucracies govern, there can be no real value pluralism, or communicative or perspectival pluralism. If all value positions and perspectives are treated as inputs to be channelled in a vertical direction, they become neutralised as values and perspectives, and simultaneously homogenised in indistinguishable vote totals. Communication and recognition struggles need an authentic public sphere where plurality and perspective open political spaces of voice and visibility. They cannot compete with struggles for power and money within an institutional framework where arriving at a centre or atop a chain of command is the basis of political legitimacy. As long as the economic system subordinates virtually all of political life to struggles for power and money, instrumental rationality and strategy will continue to obscure communication, recognition and other political struggles centred on values rather than power and interest, and law cannot assume the universal, and specifically political function that Habermas ascribes to it. It remains technical, functionalist and caught up in the imperatives and logic of a specific form of exchange and accumulation. In order for political equality to assume a more than merely formal character, it will require an economy that de-couples equality from spurious notions of merit conceived within the narrowly competitive framework established by capitalism. This was clear to Kirchheimer who, contrary to Habermas, insisted that non-interest-based forms of decision-making are not possible where the economic system transforms citizens into clients. Although brilliant, Habermas's semi-functionalist attempt to avoid this conclusion is unconvincing.

One might finish by briefly turning to some questions raised by the other ways in which it was suggested at the beginning of this paper that Habermas's work could be interpreted. Given the amazing breadth of his reading and the depth of his analysis, this last point about Kirchheimer will 
not have escaped Habermas. Did and does Habermas feel that a consistent critique of capitalism would be politically irresponsible because more than anything else post-war Germany needed political stability rather than a socialist revolution? Finally, Habermas is correct to argue that law need not necessarily be reducible to property relations and the adjudication of class and other forms of interest and conflict, but is either wrong or naive in underestimating to what extent law is currently enmeshed in, rather than an egalitarian transcendence of, those struggles. Is Habermas quietly urging us to read Habermas against Habermas, and to ask the question: under what socio-economic conditions might law be definitively de-coupled from power and interest, and as such attain its fully political significance as the basis of collective autonomy and universal self-legislation? Or does he want to stick to his sub-division of various forms of interest and their functionalist reintegration, marked as it is by the desultory semi-appropriations of other people's work that this project has assumed in his writings thus far? It would be interesting to know how Habermas might respond to these questions.

Darrow Schecter is a Reader in Critical Theory, and is currently Head of History in the School of HAHP, University of Sussex. His books have been translated into Japanese, Turkish, Spanish and German. Recent publications include 'The Critique of Instrumental Reason from Weber to Habermas' (2011) and 'Critical Theory in the Twenty-first Century' (2013). He is currently completing a book on 'Critical Theory and Sociological Theory', due to appear next year. 